VOX PATRUM 33 (2013) t. 59

Piotr KOCHANEK

\title{
PROF. DR HAB. EDWARD ZWOLSKI - DROGA INTELEKTUALNEGO ROZWOJU I DOROBEK NAUKOWO-LITERACKI ${ }^{1}$
}

Profesor E. Zwolski był wybitnym historykiem, filologiem, tłumaczem, znawcę antyku grecko-rzymskiego oraz dziejów wczesnego chrześcijaństwa. Przyszedł na świat 9 lutego 1932 r. w Warszewce ${ }^{2}$ pod Płockiem. W 1945 roku rozpoczął naukę w gimnazjum im. Stanisława Małachowskiego w Płocku.

* Dr hab. Piotr Kochanek, prof. KUL - kierownik Katedry Historii Bizancjum w Instytucie Historii na Wydziale Nauk Humanistycznych Katolickiego Uniwersytetu Lubelskiego Jana Pawła II; e-mail: pk1960jzpl@yahoo.de.

${ }^{1}$ Postawę do opracowania niniejszego życiorysu naukowego Profesora stanowiły dane, pochodzące z Archiwum KUL, nr akt: A-559. Pomocne okazały się także liczne wzmianki na temat Jego działalności naukowo-dydaktycznej, por. R. Bender - W. Müller - J. Zawadzka, Środowisko historyczne KUL, ZN KUL 1 (1958) nr 3, 128; J. Kłoczowski, Sekcja historii w latach 1944-1964, ZN KUL 8 (1968) nr 3, 59; J. Pliszczyńska-Niemirska, Pięćdziesięciolecie filologii klasycznej na Katolickim Uniwersytecie Lubelskim. Rozwój organizacyjno-personalny, RH 16 (1968) z. 3, 16-19; Z. Sułowski - Cz. Bloch, Kronika Wydziału Nauk Humanistycznych 1944-1968, w: Księga Jubileuszowa 50-lecia Katolickiego Uniwersytetu Lubelskiego, praca zbiorowa wydana w rocznicę 50-lecia istnienia uczelni, Lublin 1969, 223 i 238; S. Blacha, Studium języków obcych-lektoraty, w: Ksiega Jubileuszowa 50-lecia, s. 259-260 i 262; G. Karolewicz - E. Wiśniowski, Zarys dziejów Towarzystwa Naukowego KUL, w: Księga Jubileuszowa 50-lecia, s. 276; R. Bender, Historia na Wydziale Nauk Humanistycznych KUL (1918-1968), RH 18 (1970) z. 2, 154; Ksiega pamiątkowa w 75-lecie Katolickiego Uniwersytetu Lubelskiego. Wkład w kulture polska 1968-1993, red. M. Rusecki, Lublin 1994, 503-504; P. Kochanek, Katedra Historii Bizancjum, VoxP 23 (2003) t. 44-45, 744; K. Narecki, Katedra Historii Starożytnej, „Przegląd Uniwersytecki” 17 (2005) nr 1-2 (93-94), 45-46; T. Madała K. Narecki, Filologia klasyczna w Katolickim Uniwersytecie Lubelskim w latach 1918-2004, Lublin 2006, 68-69; Historia starożytna w Polsce. Informator, red. R. Kulesza - M. Stępień, Akme. Studia Historica, 5, Warszawa 2009, 170-171; H. Kowalski, Lublin ośrodkiem badań nad historia starożytna (1918-2010), w: Świat starożytny, jego polscy badacze i kult panujacego, red. L. Mrozewicz K. Balbuza, Gnieźnieńskie Studia Europejskie. Monografie, 4, Poznań 2011, 51-52.

${ }^{2}$ W 8-stronicowej „Ankiecie personalnej”, którą E. Zwolski wypełnił wiecznym piórem (zielony atrament) 20 listopada 1956 roku, prosząc o przyjęcie do pracy w KUL (Archiwum KUL, nr akt: A-559, pierwszy dokument tychże akt), przyszły profesor napisał odręcznie na ostatniej stronie (s. 8) swój dotychczasowy życiorys, który brzmi (zachowano oryginalną pisownię): „Urodziłem się 9.II.1932 r. w Warszewce p. Płock [...]. Do wybuchu wojny byłem przy rodzinie. Na początku okupacji zostaliśmy przez Niemców wysiedleni. Niebawem zmarł ojciec. Po wojnie byłem pod opieką siostry aż do matury, którą uzyskałem w 1950 r. w Gdyni. Potem studiowałem na KUL-u historię i fil. klasyczną, utrzymując się ze stypendiów i różnych zarobków pobocznych. W r. 1955 uzyska- 
Szkołę średnią ukończył egzaminem maturalnym w Gdyni w roku 1950, gdzie mieszkał przy ul. Warszawskiej 64/9. W tym samym roku rozpoczął studia historyczne w KUL, gdzie był uczniem prof. Jana S. Łosia (21 X 1890 - 14 I 1974). Studia te ukończył, broniąc 31 I 1955 roku o godzinie 17:00 pracę magisterską pt. Rzymska poezja złotego wieku na usługach propagandy Augusta (ss. 37) (dyplom nr 807, wydany 19 II 1955). Recenzentką tego magisterium była dr Leokadia Małunowicz (4 X 1910 - 1 V 1980), a przewodniczącym komisji prof. Andrzej Wojtkowski (20 XI 1891 - 7 VI 1975). Równolegle z historią E. Zwolski studiował też filologię klasyczną, którą zwieńczył w 21 XII 1955 roku obroną pracy magisterskiej napisanej pod kierunkiem ówczesnej dr L. Małunowicz nt. Wellejusz Paterkulus, wstep i przekład (ss. XXII + 49) (dyplom nr 1133, wydany 22 XII 1955). Pracę tę recenzował prof. J.S. Łoś, a przewodniczącym komisji był jak i poprzednio prof. A. Wojtkowski. Po ukończeniu studiów E. Zwoski wraca do Gdyni, gdzie od 1 stycznia 1956 r. do 31 października 1956 r. pracuje w szkole podstawowej nr 12. Następnie rozpoczyna pracę nad doktoratem (zwanym wówczas pracą kandydacką) i od 1 listopada 1956 r. prowadzi w KUL-u zajęcia zlecone (ćwiczenia z języka łacińskiego dla studentów I i II roku historii). 1 października 1957 roku zostaje asystentem w Katedrze Historii Starożytnej, kierowanej wówczas przez prof. J.S. Łosia. W tymże roku akademickim 1957/1958 prowadzi też zajęcia zlecone na sekcji filologii klasycznej. Jednak na stanowisku tym przepracował zaledwie rok, ponieważ 9 października 1958 r. wyjechał do Włoch i tam rozpoczął studia na Uniwersytecie Rzymskim „La Sapienza” pod kierunkiem znanego archeologa i epigrafika prof. Margherity Guarducci (20 XII 1902 - 2 IX 1999). 9 lipca 1960 r. uzyskuje w Rzymie doktorat na podstawie dysertacji La costituzione politica di Argos. Jego ówczesny włoski adres brzmiał: Roma, Via dei Barbieri 22A (w bezpośrednim sąsiedztwie ruin zespołu antycznych świątyń przy Largo di Torre Argentina). W czasie swych rzymskich studiów otrzymał wsparcie przynajmniej dwóch instytucji: stypendium Ambasady Włoch w Warszawie oraz stypendium Fundacji im. Ignacego Paderewskiego (The Paderewski Foundation) z USA. Pracownik tej ostatniej instytucji opublikował nawet swego czasu fragment listu E. Zwolskiego, w którym ten ostatni dziękował Fundacji za okazaną pomoc:

„Edward Zwolski of Lublin Catholic University wrote us as follows on August 30, 1960: «I am happy to inform you that I have just obtained the degree of Doctor 'in lettere' at the University of Rome after successfully defending my thesis entitled 'Remarks on the Political System of Argos', prepared under the guidance of Professor M. Guarducci. My grade 110 with commendation is the highest attainable at this university. I take this opportunity to express my most

łem dwa magisteria. Od stycznia 1956 r. pracowałem jako nauczyciel w Gdyni. Obecnie mam pisać pracę kandydacką i jednocześnie prowadzić ćwiczenia z łaciny. Edward Zwolski”. 
cordial thanks to the Paderewski Foundation whose invaluable assistance enabled me to complete my studies»" "3.

Z opowieści samego Profesora wiadomo jednak, że nie zawsze w czasie swych rzymskich studiów mógł liczyć na takie instytucjonalne wsparcie finansowe. Niekiedy wiązał przysłowiowy koniec z końcem udzielając maturzystom korepetycji z języka greckiego. Następnie E. Zwolski kieruje swe kroki do Eberhard Karls Universität w Tybindze, aby w roku akademickim 1960/1961 (a dokładnie do 1 III 1961) uczestniczyć w seminarium znanego historyka starożytnego prof. Josepha Vogta (23 VI 1895 - 14 VII 1986). Jego ówczesny adres to: Tübingen, Rossbergstr. 49. Resztę semestru letniego 1960/1961 spędza pracowicie w Londynie (adres: 21 Earls Court Sq., London, S.W. 5), mając za warsztat pracy British Library i British Museum. Po powrocie do Polski od 1 października 1961 r. pracował znów w KUL jako starszy asystent. W tym czasie został członkiem Towarzystwa Naukowego KUL. Mieszkał wówczas wraz z rodziną najpierw przy ul. Chopina 29/11, a później kolejno w kilku mieszkaniach przy ul. Sławińskiego 8 (nr 87, 95 i 96) (dziś: ul. Niecała). W rok później, czyli jesienią roku 1962, staje się jednym ze słuchaczy seminarium doktoranckiego prowadzonego przez prof. Izabelę Bieżuńską-Małowist (1 I 1917 - 27 VII 1995), kierującą wówczas w Instytucie Historii UW Katedrą Historii Starożytnej. Tam też w czerwcu 1963 r. otwiera przewód doktorski, a 24 października 1964 roku uzyskuje stopień doktora nauk humanistycznych na podstawie rozprawy Ustrój państwowy w starożytnym Argos (druk: Lublin 1967). Promotorem rozprawy doktorskiej jest prof. I. Bieżuńską-Małowist, a recenzentami: prof. Marian Plezia (26 II 1917 - 3 XI 1996) i prof. Józef W. Wolski (19 III 1910 - 2 X 2008) ${ }^{4}$. Stopień naukowy został oficjalnie nadany przez Radę Wydziału Historycznego UW 5 stycznia 1965 r. Konsekwencją uzyskania tego stopnie jest awans na adiunkta (1 II 1965) i powierzenie wykładów z historii starożytnej w KUL. W tym czasie E. Zwolski powrócił też do prowadzenia zajęć zleconych w ramach sekcji filologii klasycznej (zajęcia te odbywały się w roku akademickim 1961/1962, 1964/1965 i 1965/1966), a także zainicjował lektorat języka hiszpańskiego, który odbywał się w roku akademickim 1962/1963 i 1963/1964, i miał dla prowadzącego charakter zajęć dodatkowych. Od października 1969 r. do końca marca 1971 r. oraz w roku akademickim 1974/1975 E. Zwolski przebywał ponownie w ośrodkach naukowych Zachodu, głównie we Francji (Paryż) oraz w Belgii (Leuven) i Holandii (Nijmegen) ${ }^{5}$, przygotowując tam rozprawę habilitacyjną.

${ }^{3}$ E.S. Witkowski, Recent Activities of the Paderewski Foundation of New York, „Études Slaves et Est-Européennes/Slavic and East-European Studies" 5 (1960-1961) nr 3-4, 231.

${ }^{4}$ Por. Spis prac doktorskich Wydziału Historycznego 1953-1990 - www.ihuw.pl/images/dzialalnosc/doktoraty-ih.pdf [dostęp: 20 VIII 2013].

${ }^{5}$ Profesor E. Zwolski również później przebywał często na zagranicznych stypendiach, m.in. semestr letni roku akademickiego 1978/1979 spędził w Ludwig-Maximilians-Universität w Monachium. Wiele razy w okresie wakacji pracował naukowo w Belgii, w Katholieke Universiteit Leu- 
6 grudnia 1975 r. odbyło się na UW jego kolokwium habilitacyjne zakończone nadaniem E. Zwolskiemu przez Radę Wydziału Historycznego UW stopienia naukowego doktora habilitowanego nauk humanistycznych w zakresie historii starożytnej. 5 lipca 1976 roku stopień ten został zatwierdzony przez Centralną Komisję Kwalifikacyjną do Spraw Kadr Naukowych. Recenzentami w przewodzie habilitacyjnym byli: I. Bieżuńska-Małowist, Pierre Lévêque (11 VIII 1921 - 5 III 2004) i M. Plezia. Kolokwium habilitacyjne na temat Taniec sakralny w Grecji odbyło się w języku francuskim. Rozprawa habilitacyjna ukazała się drukiem w roku 1978 pt. Choreia. Muza i bóstwo w religii greckiej. Uzyskanie tego stopnia skutkuje przyznaniem docentury uchwałą Senatu KUL z 10 grudnia 1976 r., którą 27 maja 1977 r. zatwierdziło Ministerstwo Nauki, Szkolnictwa i Techniki. Na stanowisku docenta E. Zwolski został zatrudniony od 1 czerwca 1977 r. Natomiast 17 grudnia 1977 r. Senat KUL oficjalnie powierzył doc. E. Zwolskiemu kierownictwo Katedry Historii Starożytnej na WNH KUL, które sprawował 20 lat. Ostatni awans naukowy otrzymał 21 XI 1992 r. Było nim powołanie na stanowisko profesora nadzwyczajnego na okres 5-ciu lat. W sumie E. Zwolski był związany z KUL-em przez 47 lat, z czego 41 lat jako pracownik naukowo-dydaktyczny. W tym czasie opublikował około 100 prac naukowych i przekładów, z których kilka wyszło już po śmierci Autora, oraz wykształcił 9 magistrów ${ }^{6}$ (Jan Bulas, Krzysztof Gawryś, Krzysztof Gębura ${ }^{7}$, Piotr Kochanek, Jadwiga Kosalla, Wiesław Łoś, Andrzej Petri, Monika Rudaś-Grodzka, Lech Trzcionkowski) ${ }^{8}$. Zmarł w Konstancinie po długiej i ciężkiej chorobie w piątek, 19 września 1997 r., około godz. 12:00. Uroczystości pogrzebowe odbyły się w Kościele Akademickim KUL we wtorek, 23 września 1997 r., o godz. 13:00. W czasie Mszy głównym celebransem był ks. prof. Remigiusz Popowski SDB, ówczesny dziekan Wydziału Nauk Humanistycznych KUL, a homilię wygłosił ks. Wacław Oszajca SJ. E. Zwol-

ven. Niżej podpisany spotkał się z Profesorem po raz ostatni właśnie w Leuven, w drugą niedzielę sierpnia 1995 roku, w Justus Lipsius College (Minderbroedersstraat, 15). Było upalne letnie popołudniu, a rozmowa w Jego „kolegialnym” pokoju na parterze dotyczyła celtyckich krzyży.

${ }^{6}$ E. Zwolski kierował również de facto pracą magisterską Adama Konderaka (28 VIII 1946 14 VII 2001) pt. Grecka monarchia patriarchalna (Lublin 1973, ss. 63). Ponieważ jednak w tym czasie nie posiadał jeszcze stopnia doktora habilitowanego, stąd de iure jako kierownik tego magisterium figuruje w Archiwum KUL prof. Zygmunt Sułowski (2 V 1920 - 12 II 1995).

${ }^{7} \mathrm{~K}$. Gębura de facto pisał swój doktorat (Typy nazw miesięcy w kalendarzach greckich) pod kierunkiem E. Zwolskiego. Jednak ostatecznie obronił go na Uniwersytecie Warszawskim (data obrony: 10 I 1990), a jego promotorem został ówczesny doc. Włodzimierz Lengauer. Recenzentami w tym przewodzie byli: prof. I. Bieżuńska-Małowist, prof. J. Łanowski (5 VI 1919 - 24 I 2000) i doc. E. Zwolski, por. Spis prac doktorskich Wydziału Historycznego 1953-1990 - www.ihuw.pl/ images/dzialalnosc/doktoraty-ih.pdf [dostęp: 20 VIII 2013].

${ }^{8} \mathrm{Z}$ tej grupy uczniów Profesora swoje pasje naukowe rozwijają dalej: K. Gębura (doktorat: 10 I 1990), P. Kochanek (doktorat: 22 XI 1989; habilitacja: 16 VII 2003), M. Rudaś-Grodzka (doktorat: 26 I 2001), L. Trzcionkowski (doktorat: 14 VI 2000). Żadna $\mathrm{z}$ tych prac nie powstała jednak pod kierunkiem prof. E. Zwolskiego. 
ski został pochowany w Lublinie w części prawosławnej cmentarza przy ul. Lipowej (sektor I, rząd 9, miejsce 14).

Obok pracy naukowej E. Zwolski poświęcił w stanie wojennym (13 XII 1981 - 22 VII 1983) bardzo dużo swojego czasu i energii działalności na rzecz osób represjonowanych ${ }^{9}$.

Postać prof. E. Zwolskiego była przywoływana w wielu wspomnieniach pośmiertnych ${ }^{10}$. Niektóre $\mathrm{z}$ nich umieszczono $\mathrm{w}$ internecie ${ }^{11}$. Istnieją też opracowania dedykowane jego pamięci ${ }^{12}$. Warto w tym kontekście dodać element, który z punktu widzenia formacji intelektualnej uczestników seminarium z historii starożytnej był swego czasu bardzo ważny. Były to dwie wyprawy naukowe do Italii, odbyte dzięki staraniom i hojności włoskich członków Towarzystwa Przyjaciół KUL, a w szczególności Pani Wandy Gawrońskiej,

${ }^{9}$ Por. E. Teske, ,, Solidarność” - pomoc w czasach próby, w: Na początku byt Lipiec, Materiały z sympozjum naukowo-historycznego, KUL, 7 czerwca 2005, red. P.P. Gach, Lublin 2005, 100; Z. Łupina, NSZZ ,Solidarność” Regionu Środkowowschodniego w podziemiu. 13 grudnia 1981-19 lutego 1989, w: Stąd ruszyła lawina .... Region Środkowowschodni NSZZ , Solidarność” 1980-1989, red. P.P. Gach, Lublin 2006, 387.

${ }^{10}$ Por. Przyjaciele i Uczniowie, Edward Zwolski. Pożegnanie, „Gazeta (Wyborcza) w Lublinie”, poniedziałek, 22 września 1997, nr 221(1991), 10; (Klepsydra od pracowników sekcji historii Wydziału Nauk Humanistycznych KUL), Edward Zwolski, „Gazeta (Wyborcza) w Lublinie”, piątek, 26 września 1997, nr 225(1995), 14; K. Gębura, Mistrz, „Solidarność. Biuletyn Informacyjny Regionu Środkowowschodniego", 42-43(396-397) (9-16 październik 1997), 7; E. Wolicka, Człowiek o mocnym istnieniu. Wspomnienie o Edwardzie Zwolskim (1932-1997), TP 51 (1997) nr 41(2518), 15; J. Rybicka, Wszyscy wrócimy do gwiazd. Wspomnienie o profesorze Edwardzie Zwolskim, „Dziennik Wschodni”, czwartek, 23 październik 1997, rok III, nr 246(568), 9; Prof. Edward Zwolski. 19 września 1997, „Gazeta (Wyborcza) w Lublinie”, piątek, 31 października 1997, nr 255(2025), 18; S. Klemczak, Scribere in aqua. Stowo o Edwardzie Zwolskim, „Principia” 18-19 (1997) 304-307; J. Koc, On jest wśród nas. Wspomnienie, „Gazeta (Wyborcza) w Lublinie”, sobota-niedziela 19-20 września 1998, nr 220(2293), 16; A. Chruszczewski, Platon-kwazary-kwarki. Wspomnienie o śp. prof. Edwardzie Zwolskim, „Przegląd Uniwersytecki”, 10 (1998) nr 1, 17 i 19; P. Goźliński, Pieśń życia czyli kwiecista strona dywanu. Pamięci prof. Edwarda Zwolskiego, cz. I-II, „Teatr” 53 (1998) nr 1(976), 34-37; tamże, nr 2(977), 46-49; A. Wielopolska, Widzieć i rozumieć, „Rzeczpospolita”, piątek 20 lutego 1998, rok XVII, nr 43(4903), 24; L. Trzcionkowski, Edward Zwolski (9 II 1932 - 19 IX 1997), ZN KUL 42 (1999) nr 1-2, 235-244; K. Gębura, Pochwała szukajacego madrości. Wspomnienie o Edwardzie Zwolskim, w: tenże, Leipomena. Okruchy z warsztatu historyka kultury antycznej, Siedlce 2001, 93-101; Przyjaciele, Edward Zwolski (9.02.1932 - 19.09.1997). Wspomnienie, „Gazeta Wyborcza. Lublin”, poniedziałek 17 września 2007, nr 217(5525), 7.

11 Por. http://nasionadlanasion.blogspot.com/2011/02/krzysztofa-gebury-wspomnienie-o.html [dostęp: 7.05.2013]; pl.wikipedia.org/wiki/Edward_Zwolski (bibliografia prac E. Zwolskiego: 33 pozycje) [dostęp: 7.05.2013]; www.kul.pl/1314.html [dostęp: 7.05.2013].

${ }^{12}$ Por. W. Oszajca, Pamięci Edka Zwolskiego, w: tenże, Zebrane po drodze, Kraków 1998, 39: „jedno jest pewne / żyjesz ku śmierci / taki jest człowieczy / heliotropizm / nic w tym dziwnego / skoro trzeba cudu / żeby nie wierzyć"; L. Wojciechowski, Najstarsze przedstawienia partykuty Drzewa Krzyża św. Przechowywanej w klasztorze dominikanów w Lublinie (Pamięci profesora Edwarda Zwolskiego), ZN KUL 41 (1998) nr 1-2, 175-183; K. Gębura, Hyperborea. Religia Greków na pótnocnych wybrzeżach Morza Czarnego, Siedlce 2009, [5:] „Izie Bieżuńskiej-Małowist i Edwardowi Zwolskiemu na Wyspie Szczęśliwych”. 
którymi kierował właśnie E. Zwolski. W tych objazdach naukowych brali udział zarówno historycy, jak i historycy sztuki w liczbie około 40-45 osób. Pierwsza wyprawa autokarowa odbyła się we wrześniu 1981 r. i trwała około dwóch tygodni. Jej uczestnicy zwiedzili wiele ważnych historycznie miejsc, a punktem docelowym tego wyjazdu był Rzym. Natomiast druga podróż, odbyta również autokarem KUL, trwała około miesiąca. Wyjazd z Lublina miał miejsce 21 września 1984 r. Granicę Polski przekroczono 22 września, aby 24 września wjechać na terytorium Włoch. Powrót zaś nastąpił 19 października ${ }^{13}$. Owa druga ekspedycja dotarła aż do Paestum (ok. $100 \mathrm{~km}$ na południe od Neapolu). Wyprawy te zdynamizowały środowisko starożytnicze KUL. Wzrosła też wówczas znacznie liczba uczestników seminarium magisterskiego, prowadzonego przez Profesora.

Podkreślić należy także ogromny talent dydaktyczny E. Zwolskiego, dzięki któremu potrafił on zainteresować słuchaczy treścią swoich zajęć. Jego wykłady nie były nigdy „,czytane z kartki”. Było to żywe wypowiadane z pasją słowo. Podobnie dynamiczny charakter miały prowadzone przez Niego seminaria. Profesor nie żałował też studentom czasu po zajęciach, wyjaśniając $\mathrm{w}$ długich niekiedy rozmowach co trudniejsze z poruszanych tam kwestii. Ten „dydaktyczny” niejako styl bycia przyciągał, obok samej tematyki zajęć, liczne audytorium. Być może właśnie dzięki owemu sposobowi prowadzenia zajęć bardzo wielu Jego uczniów (lub tylko słuchaczy Jego seminariów) zostało później pracownikami naukowymi w różnych uczelniach i instytutach badawczych w Polsce.

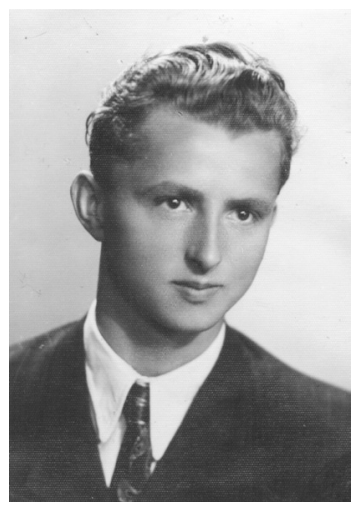

E. Zwolski, ok. 1955 r.

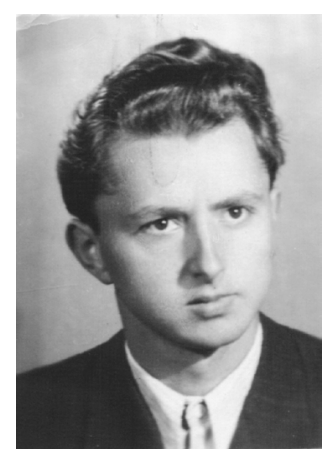

E. Zwolski, poł. lat $80 .^{*}$

\footnotetext{
* Publikowane zdjęcia pochodzą z Archiwum Uniwersyteckiego KUL.
}

${ }^{13}$ Dane te zostały podane na podstawie pieczątek wbitych w paszport piszącego te słowa przez służby graniczne państw, przez które przejeżdżał KUL-owski autokar. 
Zebrany niżej dorobek naukowo-literacki składa się z trzech części. Pierwszą (A) stanowi wykaz prac magisterskich napisanych pod kierunkiem E. Zwolskiego. Część druga (B) to bibliografia prac Profesora, do której dołączono również wykaz jego opracowań istniejących po dziś dzień tylko w maszynopisach. Wreszcie w trzeciej sekcji (C) niniejszego zestawienia zostały opublikowane po raz pierwszy 3 krótkie przekłady, istniejące dotąd w postaci pojedynczych ulotnych kartek maszynopisu.

\section{A. Prace magisterskie napisane pod kierunkiem prof. dr hab. Edwarda Zwolskiego ${ }^{14}$ (porządek chronologiczny)}

1. Gębura K., Pojęcie wieku w starożytności grecko-rzymskiej, Lublin 1978 (ss. 71).

2. Łoś W., Nekrologi w „Iliadzie”. Wokót śmierci u Homera, Lublin 1982 (ss. 147).

3. Kochanek P., Filoktet-czlowiek dniowy. Jednodniowość bohaterów tragedii Sofokles, Lublin 1984 (ss. 70).

4. Kosalla J., Cesarz Decjusz - studia krytyczne, Lublin 1984 (ss. VIII + 34 + VII).

5. Gawryś K., Pierwiastki dionizyjskie w tragediach Sofokles, Lublin 1985 (ss. 75).

6. Bulas J., Ustrój człowieka a ustrój państwa w „Państwie” Platona, Lublin 1986 (ss. 43).

7. Trzcionkowski L., Język jako źródło historyczne w pracach Emile’a Benveniste'a, Lublin 1990 (ss. 97).

8. Rudaś(-Grodzka) M., Platoński mit geograficzny, Lublin 1991 (ss. 76).

9. Petri A., Platon wobec poezji „Politei”, Lublin 1995 (ss. 182).

\section{B. Bibliografia prac prof. dr hab. E. Zwolskiego ${ }^{15}$ (w ramach poszczególnych sekcji zachowano porządek chronologiczny)}

\section{Monografie}

1. Ustrój państwowy w starożytnym Argos, Rozprawy Wydziału Historyczno-

${ }^{14}$ Opracowano na podstawie danych zaczerpniętych z Archiwum Uniwersyteckiego KUL.

${ }^{15}$ Niniejsza bibliografia opiera się na wcześniejszych, acz niekompletnych zestawieniach prac E. Zwolskiego: Gębura, Pochwała szukającego mądrości, s. 97-101 (bibliografia prac E. Zwolskiego: 56 pozycji); Madała - Narecki, Filologia klasyczna, s. 68-69 (= bibliografia prac E. Zwolskiego: 21 pozycji); pl.wikipedia.org/wiki/Edward_Zwolski (bibliografia prac E. Zwolskiego: 33 pozycje) [dostęp: 20 VIII 2013]. Dodatkowe informacje na ten temat pochodzą od Pani Zuzanny T. Zwolskiej, żony Profesora, za co w tym miejscu serdecznie Jej dziękuję. Dziękuję równie serdecznie dr. K. Gęburze za skierowanie mnie do ,archiwum haseł” EK KUL. 
-Filologicznego, 33. Studia Helleńskie, 2, Lublin 1967 (ss. 106). Recenzja: „Czasopismo Prawno-Historyczne” 23 (1971) z. 2, 236 (M. Zabłocka);

2. Choreia. Muza i bóstwo w religii greckiej, Warszawa 1978 (ss. 233). Recenzje: Milewska B., Obrzędy starożytnej Grecji, „Nowe Książki” 1979 nr 19, 96; „Eos” 69 (1981) fasc. 1, 154-155 (Cz. Mazur).

3. Demokracja w starożytności [wykład wygłoszony 18 stycznia 1981], Wszechnica Związkowa. Seria: Historyczna, Lublin [1981] (ss. 12).

4. Kasjodor i Jordanes. Historia gocka czyli scytyjska Europa, Rozprawy Wydziału Historyczno-Filologicznego 49, Lublin 1984 (ss. 171). Recenzja: „Studia Źródłoznawcze” 31 (1990) 71-72 (G. Labuda).

\section{Artykuly}

5. (1). Helena matka Konstantyna w świetle historii, ZN KUL 5 (1962) nr 2, 53-76.

6. (2). Ruchy wolnościowe na Peloponezie $w$ pierwszej połowie $V$ wieku przed Chr., RH 12 (1964) z. 2, 195-214.

7. (3). Z dyskusji nad dekretem Temistoklesa, ZN KUL 8 (1965) nr 1, 51-62.

8. (4). Akcenty propagandowe w poezji augustowskiej, RH 14 (1966) z. 3, 49-71.

9. (5). Doryzm Pindara, RH 15 (1967) z. 2, 5-16.

10. (6). Nowe źródła do dziejów wczesnej Etrurii: inskrypcje z Pyrgi, „Kwartalnik Historyczny" 75 (1968) 91-96.

11. (7). Kosmologia Alkmana, RH 16 (1968) z. 3, 31-35.

12. (8). Świat egipski u Ajschylosa, RH 16 (1968) z. 3, 37-60.

13. (9). U progu greckiej myśli eschatologicznej, ZN KUL 11 (1968) z. 1, 4557.

14. (10). Uwagi o Jordanesie historyku Gotów, „Studia Źródłoznawcze” 13 (1968) 137-145.

15. (11). W sprawie listy spartańskich Eurypontydów, PHis 59 (1968) $\mathrm{nr} 3$, 481-484.

16. (12). Tyrteusz jako źródło historyczne, RH 17 (1969) z. 3, 5-19.

17. (13). Wielka Retra i jej poetycka parafraza, RH 18 (1970) z. 2, 5-25.

18. (14). Jan Stanistaw Łoś, „Summarium” 3(23) (1974) 289-291.

19. (15). Jan Stanistaw Łoś (1890-1974), TP 28 (1974) nr 13(1314), 4.

20. (16). Klasyfikacja ustrojów u Arystotelesa. Ptynność czy ścisłość, „Biuletyn Lubelskiego Towarzystwa Naukowego $=$ Folia Societatis Scientiarum Lublinensis" 16 (1974), Humanistyka (= Humanistica) nr 2, 163-171.

21. (17). Obrzędowy aspekt walki orężnej w Grecji, RH 22 (1974) z. 2, 13-31.

22. (18). Pierwiastek muzyczny w obrzędach spartańskich, RH 23 (1975) z. 2, $5-44$.

23. (19). Morze w kulturze sumeryjskiej, w: Morze w kulturach świata, red. A. Piskozub, Wrocław 1976, 21-35. 
24. (20). „Choreia” w starożytnej Sparcie, „Biuletyn Lubelskiego Towarzystwa Naukowego = Folia Societatis Scientiarum Lublinensis" 19 (1977), Humanistyka (= Humanistica) nr 1, 21-27.

25. (21). Z historii badań nad religia i mitem. Friedrich Max Müller czyli dialektyka religii i mitologii. Biogram, RH 26 (1978) z. 2, 5-33.

26. (22). Typologia ustrojów w „Polityce” Arystotelesa. Logika a historia, PHis 70 (1979) z. 2, 253-265.

27. (23). Poncjusz Piłat, ,przyjaciel Cezara” Tyberiusza, ZN KUL 23 (1980) nr 4, 41-49.

28. (24). Gerard van der Leuuw: Fenomenologia religii, „Filozofia. Czasopismo Koła Filozoficznego Studentów KUL" 8 (1983) 6-20.

29. (25). „Litania” do celtyckiej bogini, RH 34 (1986) z. 2, 539-565.

30. (26). Sądownictwo ateńskie: rzady 1/4 nad 3/4, RH 35 (1987) z. 2, 145-158.

31. (27). Religia i polityka w Grecji. Na marginesie pięciu rozpraw o tyranii greckiej, w: Świat antyczny. Stosunki społeczne, ideologia i polityka, religia, Studia ofiarowane Izie Bieżuńskiej-Małowist w 50-lecie pracy naukowej przez jej uczniów, red. B. Bravo - J. Kolendo - W. Lengauer, Warszawa 1988, 233-255.

32. (28). Niepokój o Platona, w: Platon. Nowa interpretacja, Materiały z sympozjum, KUL, 30 listopada - 2 grudnia 1992 r., red. A. Kijewska E.I. Zieliński, Lublin 1993, 145-148. Recenzja: RuF 52 (1995) nr 1, 96-99 (A. Nowak) [o artykule E. Zwolskiego, s, 98].

\section{Recenzje}

33. (1). José María Blázquez, Imagen y mito: estudios sobre religiones mediterráneas e ibéricas, Madrid, Ediciones Cristiandad, 1977, 529, 167 ilustr., „Eos” 69 (1981) fasc. 1, 182-183.

\section{Hasła encyklopedyczne ${ }^{16}$}

34. (1). Afrodyta, EK I 132-133.

35. (2). Apollo, EK I 773-775.

36. (3). Ares, EK I 902.

${ }^{16}$ E. Zwolski miał być również autorem kilku innych haseł w EK KUL, a mianowicie: Demeter, Endymion, Eol, Europe, Gelazy I papież oraz Hunowie (religia). Hasła: Endymion, Eol i Europe miały obejmować po 10 wierszy maszynopisu. Być może z tego właśnie powodu Profesor zrezygnował z ich napisania i stąd nie widnieją one w przedmiotowej encyklopedii. Jest możliwe, że pojawią się dopiero w jej suplementach. Natomiast hasło Demeter zredagował ostatecznie ks. prof. F. Drączkowski (EK III 1142-1144), podobnie jak hasło Gelazy I papiė̇ (EK V 932). Jeśli zaś chodzi o hasło Hunowie (religia), które miało być drugą częścią hasła Hunowie i obejmować 30 wierszy maszynopisu, to prof. Z. Sułowski, autor tego ostatniego (EK VI 1333-1334), wplótł w treść tego hasła tylko niewielką wzmiankę na temat wierzeń tego ludu, ponieważ E. Zwolski zrezygnował z ich opracowania. Informacje powyższe uzyskano dzięki uprzejmości dyrektora Instytutu Leksykografii KUL, dr. E. Gigilewicza, za co w tym miejsce składam mu serdeczne podziękowanie. 
37. (4). Artemida, EK I 953-955.

38. (5). Asklepios, EK I 999-1000.

39. (6). Atena, EK I 1040-1042.

40. (7). Ateny, EK I 1044-1046.

41. (8). Biczowanie, EK II 513-514 (współautor: Józef Zbiciak).

42. (9). Bona Dea, EK II 779.

43. (10). Bóg [I 5], EK II 892-894.

44. (11). Bufonia, EK II 1183-1184.

45. (12). Dea Dia, EK III 1069.

46. (13). Dioklecjan, EK III 1334.

47. (14). Dionizos, EK III 1334-1336 (współautor: Franciszek Drączkowski).

48. (15). Domicjan, EK IV 57-58.

49. (16). Druidzi, EK IV 229.

50. (17). Edyp, EK IV 668-669.

51. (18). Egeria, EK IV 687.

52. (19). Eirene, EK IV 763.

53. (20). Eirezjone, EK IV 763.

54. (21). Elektra, EK IV 877.

55. (22). Eleusis, EK IV 881.

56. (23). Eos, EK IV 1016.

57. (24). Erechteusz, EK IV 1068.

58. (25). Erynie, EK IV 1103-1104.

59. (26). Eurydyka, EK IV 1338-1339.

\section{Przekłady z języków nowożytnych}

60. (1). Runciman S., Schizma wschodnia, tłum. J. Gawroński, przekład przejrzał i poprawił E. Zwolski, Warszawa 1963.

61. (2). Bizancjum. Wstep do cywilizacji wschodniorzymskiej, oprac. N.H. Baynes - H.S.L.B. Moss, thum. E. Zwolski, Warszawa 1964.

62. (3). Albright W.F., Od epoki kamiennej do chrześcijaństwa, thum. E. Zwolski, Warszawa 1967.

63. (4). Bravo B., Philologia. Przyczynek do badań nad kultura intelektualistów antycznych od Tukidydesa do Synezjusza i św. Augustyna, thum. E. Zwolski i A. Wyrobisz, PHis 59 (1968) z. 3, 367-405.

64. (5). Montet P., Egipt i Biblia, thum. E. Zwolski, Warszawa 1968.

65. (6). Parrot A., Biblia i starożytny świat, thum. E. Zwolski, Warszawa 1968.

66. (7). Parrot A., Wśród zabytków Samarii i Jerozolimy, tłum. E. Zwolski, Warszawa 1971.

67. (8). Philibert M., Paul Ricoeur czyli wolność na miarę nadziei. (Szkic o twórczości i wybór tekstów), tłum. E. Bieńkowska - H. Bortnowska - S. Cichowicz, przekład przejrzał E. Zwolski, Warszawa 1976.

68. (9). Pannenberg W., Kim jest człowiek: współczesna antropologia w świe- 
tle teologii, thum. E. Zwolski i D. Szumska, Znaki Czasu, 35, Paris 1978.

69. (10). Basset B., Zacznijmy znów modlić się, Znaki Czasu, 36, tłum. E. Zwolski, Paris 1979.

70. (11). Siniscalco P., Człowiek wobec świata. Aspekty religijne, etyczne i społeczne u pisarzy chrześcijańskich IV wieku, tłum. E. Zwolski, RTK 27 (1980) z. 4, 167-178.

71. (12). Buber M., Opowieści rabina Nachmana, thum. E Zwolski, Znaki Czasu, 48, Paris 1983.

72. (13). Schopenhauer A., Do Kanta, thum. E. Zwolski, „Principia” 5 (1992) 65 (na s. 64 znajduje się tekst niemieckiego oryginału: An Kant).

73. (14). Schopenhauer A., Do Madonny Sykstyńskiej, thum. E. Zwolski, „Principia” 5 (1992) s. 65 (na s. 64 znajduje się tekst niemieckiego oryginału: Auf die Sikstinische Madonna).

74. (15). Postowie: Mistycyzm żydowski, Rabin Nachman z Bracławia, Stowa rabina Nachmana, Opowiadania, thum. E. Zwolski, w: Puste krzesła. Odnaleźć radość i nadzieję, Ponadczasowa madrość chasydzkiego mistrza rabbiego Nachmana z Bracławia, opracowanie zbioru M. Mykoff i Breslov Research Institute, thum. J. Moderski, Poznań 1996, 118-148 ${ }^{17}$.

75. (16). Hölderlin F., Rozstanie, roboczy przekład E. Zwolskiego, „Principia” 18-19 (1997) 309 (na s. 308 znajduje się tekst niemieckiego oryginału: Der Abschied).

76. (17). Juarroz R., Życie ma swoja muzykę tta, thum. E. Zwolski ${ }^{18}$, w: E. Wolicka, Człowiek o mocnym istnieniu. Wspomnienie o Edwardzie Zwolskim (1932-1997), TP 51 (1997) nr 41(2518), 15.

77. (18). Dante, Paradiso, canto 22, thum. E. Zwolski, w: L. Trzcionkowski, Edward Zwolski (9 II 1932 - 19 IX 1997), ZN KUL 42 (1999) nr 1-2, 243-244.

78. (19). Skubiszewski P., Sztuka Europy tacińskiej od VI do IX wieku, thum. J. Kuczyńska i E. Zwolski, Źródła i Monografie TN KUL, Lublin 2001, 216.

79. (20). Do Chrystusa na krzyżu. (Anonimowy sonet hiszpański z XVII wie$\mathrm{ku}$ ), patrz niżej.

80. (21). Machado A., Zawołał do mego serce w jasny dzień..., patrz niżej.

81. (22). Litania do Błogosławionej Marii Panny (Litania Loretańska), zob. niżej.

\section{Przekłady źródel greckich, hebrajskich i lacińskich}

82. (1). Walerian Magni (Valerianus Magnus), Naoczny dowód możliwości istnienia próżni, część I-II, thum. E. Zwolski, tłumaczenie zredagował i do druku przygotował M. Subotowicz, „Kwartalnik Historii Nauki i Techni-

${ }^{17}$ Jest to przedruk z: M. Buber, Opowieści rabina Nachmana, thum. E. Zwolski, Znaki Czasu, 48, Paris 1983, 13-32.

${ }^{18}$ Wiersz R. Juarroza (5 X 1925 - 31 III 1995) nosi w oryginale tytuł „La vida tiene una música de fondo" i jest 32. utworem zbioru Octava poesía vertical (rutynowy zapis: Poesía vertical, VIII 32), którego pierwsze wydanie ukazało się w roku 1984, por. R. Juarroz, Octava poesía vertical, Buenos Aires 1984. Por. też tenże, Poesía vertical: 1983-1993, Buenos Aires 1993. 
ki" 4 (1959) nr 1, 77-99.

83. (2). Walerian Magni (Valerianus Magnus), Obrona W. Magniego przed zarzutem plagiatu (list do Robervala), thum. E. Zwolski, thumaczenie zredagował i do druku przygotował M. Subotowicz, „Kwartalnik Historii Nauki i Techniki" 4 (1959) nr 1, 100-104.

84. (3). Wellejusz Paterkulus, Historia rzymska, wstępem i komentarzem opatrzył E. Zwolski, Biblioteka Przekładów z Literatury Antycznej, 16, Warszawa 1970. Recenzja: „Eos” 61 (1973) fasc. 1, 157-159 (I. Lewandowski).

85. (4). Walerian Magni, Naoczny dowód możliwości istnienia próżni, część II, thum. E. Zwolski, w: Filozofia i myśl społeczna XVII wieku, cz. 2, wybrał, opracował, wstępem i przypisami opatrzył Z. Ogonowski, Z Prac Zakładu Historii Polskiej Filozofii Nowożytnej i Socjologii PAN; 700 Lat Myśli Polskiej, Warszawa 1979, 188-192.

86. (5). Walerian Magni, List do Robelwara zawierajacy obrone przed zarzutami plagiatu, tłum. E. Zwolski, w: Filozofia i myśl społeczna XVII wieku, cz. 2, s. 192-195.

87. (6). Caius Velleius Paterculus, Teoria rozwoju i upadku gatunków literackich, tłum. E. Zwolski, w: Rzymska krytyka i teoria literatury. Wybór, oprac. S. Stabryła, Biblioteka Narodowa, seria 2, nr 207, Wrocław 1983, 69-73.

88. (7). Jordanes, O pochodzeniu i czynach Gotów, w: E. Zwolski, Kasjodor $i$ Jordanes. Historia gocka czyli scytyjska Europa, Rozprawy Wydziału Historyczno-Filologicznego, 49, Lublin 1984, 91-171.

89. (8). Pieśn nad Pieśniami, tłum. E. Zwolski, Jędrzejów-Lublin 1991. Recenzje: (JAC), Bibliofilski rarytas, ,Słowo Powszechne” 46 (1992) nr 69, 6; (jotka), Czytać, „Gazeta Wyborcza”, sobota-niedziela 6-7 czerwca 1992, nr 133, 17; L.W., Pieśń nad pieśniami, „Nowy Świat”, wtorek 14 kwietnia 1992, rok II, nr 89(114), 10; Masłoń K., Zmysty i sacrum, „Rzeczpospolita”, czwartek 12 marca 1992, rok XI, nr 61(3099), 4; Żółciński T.J., Czas pieśni na ziemi!, „Słowo Żydowskie = Dos Jidisze Wort”, 8 maja 1992, nr 9(9), 14.

90. (9). Platon, Biesiada, przekład i słowo towarzyszące E. Zwolski, Biblioteka Principia. Stoicheia, 1, Kraków 1993. Recenzje: Goźliński P., Arcydialog Platona, „Życie Warszawy”, wtorek 17 maja 1994, nr 114, codzienny dodatek: „Życie Ekstra”, s. V; Koss M., Miłosny Platon i mysteryjny, „Znak” 46 (1994) nr 12(475), 141-144; c) RuF 52 (1995) nr 1, 95-96 (L. Regner); Stebnicka K., Uczta, biesiada czy balanga?, „Regiony” $1995 \mathrm{nr} 2$, 122125; Rybowska J., O polskich przekładach „Uczty” $i$ „Fedona”, „Meander" 51 (1996) nr 3-4, 163-168 [o przekładzie E. Zwolskiego, s. 165-167].

91. (10). Platon, Phaidros, przekład i słowo towarzyszące E. Zwolski, Biblioteka Principia. Stoicheia, 2, Kraków 1996. 
92. (11). Platon, Phileb, thum. E. Zwolski, Biblioteka Principia. Stoicheia, 3, Kraków 1999.

93. (12). Platon, Biesiada, przekład i słowo towarzyszące E. Zwolski, Arcydzieła Wielkich Myślicieli, Warszawa 2001.

94. (13). Caius Velleius Paterculus, Teoria rozwoju i upadku gatunków literackich, tłum. E. Zwolski, w: Rzymska krytyka i teoria literatury (wybór), t. 1, oprac. S. Stabryła, Arcydzieła Kultury Antycznej, Wrocław - Warszawa 2005, 72-76.

95. (14). Wellejusz Paterkulus, Historia rzymska, przekład, wstęp i komentarz E. Zwolski, Arcydzieła Kultury Antycznej, Wrocław - Warszawa 2006.

\section{Inedita ${ }^{19}$}

96. (1) Hymn(y) z Rig-wedy, thum. E Zwolski ${ }^{20}$.

97. (2) Juarroz R., Strefy metafizyczne, tłum. E. Zwolski²1.

98. (3) Dante, Boska komedia, thum. E. Zwolski².

99. (4) Horacy, Poezje, thum. E. Zwolski23.

100. (5) Szekspir, Sonety, thum. E. Zwolski ${ }^{24}$.

101. (6) Marek Aureliusz, Rozmyślania, tłum. E. Zwolski²5.

${ }^{19}$ Najobszerniejszą wiedzę na temat nie wydanych opracowań i przekładów E. Zwolskiego posiada dr L. Trzcionkowski. Wiele w tym względzie miał też do powiedzenia ś.p. prof. Janusz A. Drob (12 II 1952 - 3 II 2011), którego E. Zwolski cenił i bardzo szanował.

${ }^{20}$ Wspomina o tym sam Autor w liście do Pani Jadwigi Koc, pisanym w Leuven i datowanym na 5 lipca 1984: „Wczoraj, po kilku dniach, przetłumaczyłem mój pierwszy hymn z Rig-wedy. Jest krótki - wszystkiego 30 wierszy. Kończy się prosto: «Bądź dla nas, Boże, łatwo dostępny, / jak ojciec dla syna / i prowadź nas ku dobremu byciu». Tak modlono się w Indiach gdzieś w XII wieku przed narodzeniem Chrystusa: «Bądź dla nas, Boże, [...] jak ojciec dla syna [...]»". W tym miejsce dziękuję bardzo Pani J. Koc za powyższe informacje (por. noty: 22 i 23).

${ }^{21}$ Wiadomość na ten temat znajduje się w: Gębura, Pochwała szukajacego madrości, s. 100 (pozycja 40). Dr K. Gębura miał uzyskać tę informację bezpośrednio od Profesora. Jednak E. Zwolski nie zdążył już opublikować tego przekładu. R. Juarroz (por. nota. 18) opublikował między rokiem 1958 a 1993 aż 13 zbiorów poezji pod wspólnym tytułem Poesía vertical, którym nadawał kolejne numery (od 1 do 13). Jest to w sumie około tysiąca utworów, por. wydanie kompletne R. Juarroz, Poesía vertical, I, Buenos Aires, Emecé, 2005 (ss. 519); tenże, Poesía vertical, II, Buenos Aires 2005 (ss. 567). E. Zwolski bez wątpienia nie przełożył w całości owego opus vitae R. Juarroza, lecz pewną liczbę zawartych w nim poematów. Kwestią do ustalenia pozostaje ile ich było i kto posiada ich maszynopisy.

${ }^{22}$ Profesor thumaczył głównie pieśni z „Raju” i „Piekła”. Wiadomości te pochodzę od dr Stefana Klemczaka (UJ). Maszynopisy tych przekładów zachowały się zapewne u niektórych uczestników seminarium Profesora.

${ }^{23}$ Informacja pochodzi od dr. S. Klemczaka.

${ }^{24}$ Informacja pochodzi od dr. S. Klemczaka.

${ }^{25}$ Informacja pochodzi od dr. S. Klemczaka. 


\title{
C. Niektóre nie wydane dotąd przekłady
}

\author{
Do Chrystusa na krzyż ${ }^{26}$ \\ (Anonimowy sonet hiszpański z XVII wieku)
}

Nie porusza mnie, Boże mój, by cię kochać, niebo twojej obietnicy i nie porusza mnie widmo piekła, by nie obrażać cię, z lęku.

Ty poruszasz mnie, Panie. Poruszasz mnie przybity do krzyża i wzgardzony, porusza mnie twe ciało $\mathrm{w}$ ranach, poruszają mnie twe zniewagi i twoja śmierć.

Porusza mnie, wreszcie, twoja miłość, i tak porusza, że i bez nieba bym cię kochał, i bez piekła drżałbym przed tobą.

Nie musisz mi dać nic za to, bym cię kochał, bo nawet bez nadziei, którą żyję, tak samo bym cię kochał, jak cię kocham.

\section{Antonio Machado ${ }^{27}$ \\ Zawolat do mego serca w jasny dzień...}

Zawołał do mego serca w jasny dzień

z wonią jaśminów wiatr.

- W zamian za ten zapach

chcę cały zapach twoich róż.

- Nie mam róż; kwiaty

w moim ogrodzie nie rosną; wszystkie umarły.

${ }^{26}$ Sonet ten, przypisywany m.in. św. Janowi z Awila (6 I 1500 - 10 V 1569), czy św. Teresie z Awila (28 III 1515 - 4 X 1582), nosi w oryginale tytu1: Soneto a Cristo crucificado. Funkcjonuje też pod tytułem No me muove, mi Dios, para quererte, ponieważ tak brzmi jego pierwszy wers. Sonet ten miał krążyć długo w odręcznych odpisach, aż wreszcie w roku 1628 umieścił go w swym drukowanym w Madrycie dziele La vida del espírito Antonio de Rojas (1585-1650), por. es.wikipedia.org/wiki/Soneto_a_Cristo_crucificado. Przekład ten (w maszynopisie) E. Zwolski dedykował Pani J. Koc 10 grudnia 1982 roku. Sama dedykacja została dodana odręcznie.

${ }^{27}$ Oryginalny tytuł tego utworu A. Machado (26 VII 1875 - 22 II 1939) brzmi: Llamó a mi corazón, un claro día. Wiersz ten ukazał się w roku $1907 \mathrm{w}$ tomie poezji A. Machado zatytułowanym: Soledades, Galerías y Otros poemas. Jego przekład pióra E. Zwolskiego zachował się w maszynopisie w zbiorach archiwalnych Pani J. Koc. Maszynopis ów nie jest niestety datowany. Wiersza tego nie ma w przełożonym na polski wyborze utworów tego poety, por. A. Machado, Serce i kamień. Wybór poezji, thum. A. Międzyrzecki, Warszawa 1967. 
- Uniosę płacze źródeł,

pożółkłe liście i płatki zwiędłe.

I wiatr uciekł... Moje serce krwawiło...

Duszo, co uczyniłaś z moim biednym ogrodem!

\section{Litania do Błogosławionej Marii Panny ${ }^{28}$ \\ (Litaniae ad Beatam Mariam Virginem)}

Sancta Maria

Sancta Dei Genitrix

Sancta Virgo virginum

Mater Christi

Mater Divinae gratiae

Mater purissima

Mater castissima

Mater inviolata

Mater intemerata

Mater amabilis

Mater admirabilis

Mater boni consilii

Mater Creatoris

Mater Salvatoris

Virgo prudentissima

Virgo reverenda

Virgo praedicanda

Virgo potens

Virgo clemens

Virgo fidelis
Święta Mario

Święta Boga Rodzico

Święta Panno nad pannami

Matko Chrystusa

Matko Łaski Bożej

Matko najczystsza

Matko najskromniejsza

Matko, sile nie uległa

Matko, na zuchwałość nie podana

Matko, miłość budząca

Matko, podziwu godna

Matko dobrej rady

Matko Stworzyciela

Matko Odkupiciela

Panno najroztropniejsza

Panno do czci przeznaczona

Panno do sławy powołana

Panno można

Panno łagodna

Panno wierna

${ }^{28}$ Jest to thumaczenie „Litanii Loretańskiej” w takiej formie jaką miała ona w czasie, gdy papież Klemensa VIII (24 II 1536 - 3 III 1605, papież od 30 I 1592) nakazał w roku 1601 dekretem Quoniam multi wprowadzić w Kościele jednolity tekst tej modlitwy i zabronił jej modyfikacji bez zgody Rzymu. W konsekwencji powyższy przekład nie zawiera wezwań, które pojawiły się później, a którymi są: Regina sine labe originali concepta (1874), Regina sacratissimi rosarii (1883), Mater boni consilii (1903), Regina pacis (1917), Regina in caelum assumpta (1950). Następnie dodano wezwania: Mater Ecclesiae (1980) i Regina familiae (1995). W Polsce zaś, jak wiadomo, funkcjonuje też wezwanie Regina Poloniae. Jest to zmodyfikowany po II wojnie światowej tytuł Maryi, który wcześniej (oficjalnie od roku 1923) brzmiał Regina Regni Poloniae, por. A. Baron, Le culte de la Très Sainte Vierge à Lorette, w: Maria. Études sur la Sainte Vierge, sous la direction d'Hubert Du Manoir S.J., t. 4, Paris 1956, 95-96; J. Duchniewski, Litania Loretańska, 1, EK X 1171-1173. E. Zwolski przeoczył tylko fakt, że wspomniane wyżej wezwanie Mater boni consilii zostało dodane dopiero w roku 1903, stąd zamieścił je w swojej wersji przekładu. Przekład ten, dokonany w maju 1997 roku, w czasie pobytu Profesora w szpitalu, otrzymał niżej podpisany w formie kserokopii wydruku komputerowego od Pani Z. T. Zwolskiej, za co w tym miejscu składam Jej serdeczne podziękowanie. 
Speculum justitiae

Sedes sapientiae

Causa nostrae laetitiae

Vas spirituale

Vas honorabile

Vas insigne devotionis

Rosa mystica

Turris Davidica

Turris eburnea

Domus aurea

Foederis arca

Janua caeli

Stella matutina

Salus infirmorum

Refugium peccatorum

Consolatrix afflictorum

Regina Angelorum

Regina Patriarcharum

Regina Prophetarum

Regina Apostolorum

Regina Martyrum

Regina Confessorum

Regina Virginum

Regina Sanctorum omnium
Zwierciadło Sprawiedliwości

Tronie Mądrości

Przyczyno naszej radości

Naczynie duchowe

Naczynie zaszczytne

Dostojne naczynie pobożności

Różo mistyczna

Wieżo Dawidowa

Wieżo z kości słoniowej

Domie złoty

Arko przymierza

Bramo niebieska

Gwiazdo zaranna

Uzdrowienie chorych

Ucieczko grzesznych

Pocieszycielko strapionych

Królowo aniołów

Królowo patriarchów

Królowo proroków

Królowo apostołów

Królowo męczenników

Królowo wyznawców

Królowo panien

Królowo wszystkich świętych

\section{PROFESSOR EDWARD ZWOLSKI \\ - HIS LIFE AND SCIENTIFIC ACHIEVEMENTS}

(Summary)

This article provides a brief biography of Edward Zwolskiego, an eminent Polish scholar of ancient history, and a bibliography of his publications, as well as some of his unpublished translations. E. Zwolski was born in 1932 and died September 19, 1997. He was a professor at the Catholic University of Lublin for over 40 years. He left about 100 publications. Professor E. Zwolski was known not only as an excellent researcher, but also as a very good teacher.

Słowa kluczowe: Edward Zwolski, biografia, bibliografia.

Key words: Edward Zwolski, biography, bibliography. 